\title{
THE REASONS OF NON-INSTITUTIONAL CHARACTER OF THE EARLY VISEGRAD COOPERATION IN THE VIEW OF NEOREALIST AND NEOLIBERAL THEORIES IN INTERNATIONAL RELATIONS
}

ABSTRACT This article examines the reasons for adopting a non-institutional character of the Visegrad cooperation in the years 1991-1992. Its focus concerns two causes of the initial reluctance to institutionalise the Visegrad Group: the high level of unpredictability in Central Europe after the collapse of Communism and the symbolic role the Group was expected to play outside the region. These issues are considered through the prism of two theories in International Relations: neorealism and neoliberal institutionalism. Both provide theoretical grounds to support the research hypothesis which assumes that the informal character of the Visegrad cooperation was a pragmatic choice of its founding members. However, neorealist and neoliberal explanations of how the political background and security issues could have influenced their decision vary. The article concludes that the neorealist approach holds more explanatory power in this regard, suggesting that the choice of the Visegrad states was dictated by the preservation of their national interests and subjected to external limitations, rather than motivated by a common intention to facilitate their regional cooperation.

KEYWORDS Visegrad Group, VG, neorealism, neoliberal institutionalism, noninstitutional cooperation 


\section{INTRODUCTION}

The Visegrad Group $(\mathrm{VG})^{1}$ was created as a forum of regional cooperation in Central Europe (CE) under the so-called 'Visegrad Declaration' (Visegrad, 15 February 1991)². Among the founding members were three post-communists states undergoing transition from state socialism with a centrally planned economy to democracy with a free-market economy: Poland, Czechoslovakia, and Hungary. As follows from the full name of the Visegrad Declaration: Declaration on Cooperation between the Czech and Slovak Federal Republic, the Republic of Poland and the Republic of Hungary in Striving for European Integration ${ }^{3}$, the main purpose of the cooperation was to accelerate the integration with the European political, economic and military groupings. Beside this, all the three states were interested in the restoration of regional security after the collapse of Communism in Central and Eastern Europe. Their similar, but not identical political objectives, economic conditions, and security dilemmas resulted from their geographical proximity and correlated historical experience of the recent decades, namely the fact that they have belonged to the Soviet bloc since the end of World War II.

The will for political cooperation in the face of common challenges of the transition period and shared aspirations towards integration with European institutions have proved to be an insufficient reason for the establishment of a new regional organisation in CE. Instead of this, the VG (originally the Visegrad 3) was designed as a platform of regional cooperation, adopting the informal nature of its functional and organisational modus vivendi $i^{4}$. The reasons lying behind such a development are the main subject of

1 The Visegrad Group is presently referred to as the 'V4'. Because the present paper focuses on its functioning in the period of 1991-1992, during which it consisted of three members (Poland, Czechoslovakia, Hungary), the use of acronym ' $V G$ ' is considered to be more appropriate.

2 In the Declaration of 1991 the term 'Central Europe' is used to determine the geographic scope of the Visegrad Group. In this respect, the Declaration is an attempt to distinguish three Visegrad states from the region of Central and Eastern Europe, into which they were previously included. In the present paper, this term refers to Poland, Czechoslovakia, and Hungary. It should be acknowledged, however, that Central Europe is a dynamic historical concept and for many authors it rather refers to a cultural than geographical region, embracing also those states which have emerged from the dissolution of the Austro-Hungarian empire. See, e.g., M. Kundera, "The Tragedy of Central Europe", The New York Review of Books, 26 IV 1984.

3 Declaration on Cooperation between the Czech and Slovak Federal Republic, the Republic of Poland and the Republic of Hungary in Striving for European Integration, adopted in Visegrád on 15 February 1991, the Visegrad Group, [online] http://www.visegradgroup.eu/documents/visegrad-declarations/ visegrad-declaration-110412, 10 II 2014.

4 The VG cannot be considered as an international organisation. However, it can be perceived as an international institution in a broad meaning of this term, adopted by scholars such as John J. Mearsheimer, who defines institutions as a set of rules that stipulate the ways in which states should cooperate and compete with each other, or Robert Keohane, who perceives them as persistent and connected sets of rules (formal or informal) that prescribe behavioral roles, constrain activity, and shape expectations. The author, however, avoids this terminology when describing the VG's early setting. Not only to emphasise its non-formal modus vivendi, which institutions may adopt as well, but to acknowledge that the rules of cooperation within the VG were not clearly determined in the Declaration of 1991 and 
consideration in this paper. Their recognition is expected to expose the underlying interests and/or intentions which drove the Central European countries (CECs) to cooperate at the beginning of the 1990s. To that end, the author intends to analyse the premises explaining the initial reluctance to institutionalise the VG through the prism of two theories in International Relations: neorealism and neoliberal institutionalism. The research hypothesis presupposes that the informal character of the Visegrad cooperation was a pragmatic choice of its founding members. Trying to justify the above statement, the author would like to examine whether their choice in its early days, namely in the period of 1991-1992, was dictated by the preservation of national interests or common intention to facilitate cooperation. The application of the above-mentioned theories to political developments in CE, which preceded and followed the collapse of communist regimes in 1989/90, should contribute to that end. The author intends to support the analysis not only with the political background, but also to refer to the security situation in the region at that time. Special emphasis is to be placed on the provisions of the Visegrad Declaration - which forms source evidence containing information about the expected scope and mechanisms of cooperation among the CECs.

The remaining part of this paper is organised in the following way: in the first step, certain theoretical considerations on neorealism and neoliberal institutionalism are provided, highlighting their different stance on international cooperation. In the second step, two premises determining the informal nature of cooperation within the VG are presented: the state of unpredictability in which the CECs found themselves after the collapse of Communism and the symbolic role that the VG was expected to play outside the region. Both of them are successively analysed with the use of neoliberal and neorealist prescriptions on states' behaviour in international institutions (formal and informal ones) $)^{5}$. The concluding section considers which approach provides more credible explanation of a decision made by the CECs to cooperate without formal structures.

\section{THEORETICAL APPROACH: NEOREALISM AND NEOLIBERAL INSTITUTIONALISM}

The theoretical frame for analysing post-1989 relations in CE, which contributed to the creation of the VG is provided by two approaches to examining international relations: neorealism and neoliberal institutionalism. Both of these are recognised as cur-

remained unclear until the approval of the Contents of Visegrád Cooperation 1999 at the May 1999 Bratislava summit. Citations from: J.J. Mearsheimer, “The False Promise of International Institutions”, International Security, vol. 19, no. 3 (1994/1995), p. 8; R. Keohane, "Neoliberal Institutionalism: A Perspective on World Politics" in R. Keohane (ed.), International institutions and state power: Essays in international relations theory, Boulder 1989, p. 3.

5 Although there are some limitations to recognising the early VG as an institution from a theoretical point of view (there were no clear and persistent rules of cooperation at the beginning of its activity), its operation was similar to the functioning of well-established institutions. This fact enables the author to analyse the reasons of its creation with the use of theories explaining states' behaviour in international institutions. 
rents of thought within the main theoretical schools of the IR field: realism and liberalism ${ }^{6}$. However, it should be noted that in the above approaches significant changes have been implemented in comparison to the proposals of their historical predecessors, i.e. classical realism and idealism. Therefore, they cannot be regarded merely as their complement or adaptation to the present developments in international relations. Before proceeding to the proper analysis, the author would like to present briefly their main assumptions and analytical significance for the inquiry held in this paper. What is especially important in the context of this work is their stance on international cooperation which reflects difference in the choice of subject matter these theories focus on: neorealism is more prone to studying international security and the causes of conflict among states, whereas neoliberal institutionalism concentrates more on economic issues and possible interdependence among states.

\subsection{Neorealism}

Neorealism, the first of two theories considered in this paper, was built on the premises of classical realism ${ }^{7}$. According to these premises, every action of a state should be interpreted as a rational way of accumulating its own power - the ability to control and influence behaviours of other states ${ }^{8}$. This approach to understanding international relations is therefore a state-centrist approach, since sovereign states are recognised as the main and unitary actors. They conduct foreign policy in the anarchic environment of the international system in pursuit of national survival and security'. Classical realism does not acknowledge the importance of international institutions in shaping the relations among states. Its exclusive focus on the national level of analysis is one of its main distinctive features in comparison to neorealism. The latter acknowledges not only the state level, but additionally perceives the whole international system as another unit of analysis (the structural level).

Neorealism takes into account the idea that relations among states may be conceived as a system with its own structure that influences states' behaviours: the idea that international politics can be thought of as a system with a precisely defined structure is neorealism's fundamental departure from traditional realism ${ }^{10}$. It provides grounds

K.E. Jørgensen, International Relations Theory. A New Introduction, London 2010, p. 13.

These were outlined by Hans J. Morgenthau as a set of six principles: (1) politics is governed by objective laws; (2) interest, defined in terms of power, is the key to understand states' behaviour; (3) the content of power is determined by the political and cultural context within which foreign policy is formulated; (4) prudence, in opposition to morality, is the main virtue in politics; (5) moral aspirations of a particular nation are not universal; (6) the political sphere should be perceived as autonomous one. H.J. Morgenthau, K.W. Thompson, Politics Among Nations: The Struggle for Power and Peace, New York 1985, pp. 4-14.

8 Ibid., p. 11.

$9 \quad$ S. Ben-Itzhak, "Realism and Neorealism" in J.T. Ishiyama, M. Breuning (eds.), $21^{\text {st }}$ Century Political Science: A Reference Handbook, 2011, p. 312.

10 K. Waltz, Theory of international politics, New York 1979, p. 127. 
to widen the analytical scope in examining international relations and acknowledge the role of international structure in shaping states' relations. This assumption of neorealism is especially meaningful in the context of this paper because it enables to examine the impact of changes in the international reality on states' behaviour.

However, neorealism, just like classical realism, does not consider international institutions as distinctive actors or units. It recognises them as a characteristic feature of the multipolar system. It sees international cooperation among states as difficult to establish and maintain and emphasises its strong dependence upon state power ${ }^{11}$. From this point of view, one should consider the activity of international institutions as an extension of national interests of cooperating states or as an instrument for their implementation. It does not depart from the basic realist's conviction that relative gains prevail over absolute ones. In this respect, neorealism remains sceptical towards the ability of international institutions to govern or mitigate systemic anarchy.

\subsection{Neoliberal institutionalism}

Neoliberalism as such derives from the liberal tradition and the interwar idealism ${ }^{12}$. However post-war liberal theories have been strongly influenced by the realist way of thinking and recognise the existence of cases where states' interests are in fundamental conflict, they maintain the claim that in many cases the conflict can be mitigated or avoided by providing arenas for cooperation among them ${ }^{13}$. The one which embraces the conviction about the importance of international regimes and organisations in the world politics is neoliberal institutionalism. It is generally considered as one of the strands of neoliberalism or contemporary liberal theory (together with pluralism, interdependence liberalism, and republican liberalism $)^{14}$. Neoliberal institutionalism refers to the idea of 'complex interdependence' which suggests that there are numerous forms of connection among states apart from the intergovernmental relations, such as transnational networks of individuals or companies ${ }^{15}$. This idea emphasises the influence of non-state actors on international relations, which binds states and makes them more interdependent upon each other.

11 E.A. Heinze, B.J. Jolliff, "Idealism and Liberalism" in J.T. Ishiyama, M. Breuning (eds.), $21^{\text {st }}$ Century..., p. 320.

12 One may summarise liberal prescriptions for international relations in four major points: (1) preference for a law-governed society of states; (2) cooperation in international organisations to collectively implement the law; (3) the spread of democracy and liberal values (e.g. political freedom, individual rights, private property); (4) the introduction of free trade as a way to achieve prosperity and peace. They presume that a harmony of interests among states can be introduced by the creation of international law and collective security system. See ibid., p. 320.

13 R. Jervis, "Realism, Neoliberalism, and Cooperation. Understanding the Debate", International Security, vol. 24, no. 1. (1999), p. 47.

14 E.A. Heinze, B.J. Jolliff, “Idealism...”, p. 323.

15 R. Keohane, J. Nye, Power and Interdependence, New York 2001, pp. 21-22, 29. 
In these circumstances, the role of international institutions gains importance as a channel of exchanging information and solving disputes among states. Firstly, institutional rules are expected to discourage cheating by creating the prospect of future gains through cooperation and making states more cautious about the consequences of their actions over time, producing the socalled 'shadow of the future' ${ }^{16}$. Secondly, common rules can reduce the 'transaction costs' of individual agreements. They are expected to facilitate the process of negotiating and monitoring agreements, as well as provide mechanisms for overcoming possible defections ${ }^{17}$. Explanations given by institutional liberalism assume that states behave rationally when they establish common rules and participate in institutions. However, contrary to the similar presumption present in interwar idealism, it agrees to define rationality in terms of selfinterest seeking or egoistic behaviour. According to Robert Keohane, even those egoistic states are interested in the establishment of international regimes, since it makes them able to achieve optimal outcomes which lay beyond their own abilities ${ }^{18}$. International cooperation should be therefore perceived as a rational attempt to conduct mutually beneficial agreements and, as a result, mitigate systemic anarchy.

\subsection{Differences and similarities between the two theories}

The above presentation illustrates some crucial differences between neorealism and neoliberal institutionalism, especially in their perception of international forms of cooperation, which derive from distinct assumptions of these theories about the fundamental concerns of states. Neorealism maintains that states are primarily concerned about relative gains and even when they decide to cooperate for a mutual gain, they in fact calculate how much they can benefit vis-á-vis each other. The two most important goals of state activity at the international level are invariably security and survival. Neoliberal institutionalism emphasises absolute gains, which means that states are expected to be primarily concerned with their own gains, without paying much attention to the gains of other states. According to neoliberal theory, they are interested in providing themselves with economic welfare and do not perceive military security as a priority in their foreign policy. Another difference between the two theories lies in the set of their explanatory variables. Neorealists interpret states' behaviour by examining the distribution of power among them and by comparing their capabilities (population, economic development, and military force $)^{19}$. Neoliberals examine not only states' capabilities and interests, but also take under consideration intentions and the distribution of information among them.

16 R. Axelrod, R. Keohane, “Achieving Cooperation under Anarchy: Strategies and Institutions”, World Politics, vol. 38, no. 1 (1985), p. 232.

17 R. Keohane, After Hegemony: Cooperation and Discord in the World Political Economy, Princeton 1984, pp. 89-92.

18 Ibid., p. 126.

19 K. Waltz, "Realist thought and neorealist theory" in R.L. Rothstein, W.T.R. Fox (eds.), The Evolution of Theory in International Relations, Columbia 1992, pp. 21-38. 
Bearing this in mind, it is important to acknowledge the fact that a more balanced approach to the debate between neorealists and neoliberal institutionalists is needed. The discrepancies between these two theories should not be exaggerated ${ }^{20}$. Scholars who consider themselves as defensive realists, such as Robert Jervis, as well as those representing the neoliberal perspective, such as Keohane and Lisa Martin, are trying to avoid a tempting simplification that neorealists perceive international relations as much more conflictual than neoliberals do, and that the former do not value international institutions at all. They emphasise that both theories are built on the assumption that states are 'rational utility maximisers' that operate in the anarchic environment of the international system. As Jervis rightly points out, both approaches recognise the absence of a sovereign authority at the international level that could enforce binding agreements among states as the main obstacle to cooperation ${ }^{21}$. Indeed, the so-called 'fear of cheating' - the fear that the other party of an agreement will cheat and benefit from reneging on its promises plays an important role in their explanation why it is difficult to establish and maintain cooperation among states. The difference between the two theories lies, however, in their position on the existence of other critical factors in states' calculations. While neoliberalism perceives the problem of cheating as a supreme obstacle hindering cooperation, neorealism recognises the inclination of states to consider relative gains as equally disruptive: they [neorealists] stress that states will often be reluctant to cooperate even if they could be certain that the counterpart will cooperate and that they will gain as a result ${ }^{22}$.

This discrepancy has far-reaching consequences for the neorealist and neoliberal stance on the role and efficiency of international institutions. It determines why neorealists perceive these institutions as purely instrumental tools of statecraft, having no capability to develop autonomously and change the preferences of the participating states, which are permanently concerned with their relative gains. For neoliberals, who maintain that the relative-gains problem is not intractable and can be successfully overridden by the absolute gains of cooperation, institutions are regarded as much more effective. They are expected to provide states with mechanisms enabling them to achieve a mutually acceptable distribution of gains, such as 'side-payments' or 'issue linkages', and satisfy their concerns as a result ${ }^{23}$. From this perspective, the activity of international institutions can enhance trust among states and simultaneously change their preferences and perception of each other, permitting new forms and degrees of cooperation.

20 See R. Jervis, "Realism...”; R. Keohane, L. Martin, "Institutional Theory as a Research Program" in C. Elman, M.F. Elman (eds.), Progress in International Relations Theory: Appraising the Field, Cambridge, MA 2003.

$21 \quad$ R. Jervis, “Realism...”, p. 43.

22 F. Andreatta, M. Koenig-Archibugi, "Which Synthesis? Strategies of Theoretical Integration and the Neorealist-Neoliberal Debate”, International Political Science Review, vol. 31, no. 2 (2010), p. 210, [online] DOI: http://dx.doi.org/10.1177/0192512110364258.

23

Ibid., p. 213. 
Although the above disagreement has been accounted by individual scholars for a difference in the issues analysed by the two theories ${ }^{24}$, it remains meaningful in the context of this paper. The inconsistency between neorealism and neoliberal institutionalism in the perception of international institutions provides two counterbalanced approaches to analyse the nature of the Visegrad cooperation in the period of 1991-1992. In accordance with the neorealist perspective, one should interpret its informal nature as a sort of weakness which results from a significant mismatch of national interests represented by particular Visegrad states. Implementing the assumptions of neoliberal theory, one may perceive the non-binding character of cooperation as an optimal way of achieving mutual gains in a changeable political environment (by providing the VG with the flexibility of actions). In order to achieve a comprehensive explanation of a decision made by the Visegrad states in 1991 to adopt the informal model of cooperation, the most plausible premises underling their choice will be successively analysed with the use of neorealist and neoliberal perspective.

\section{INFORMAL NATURE OF THE VISEGRAD COOPERATION - MAIN PREMISES}

The key document which presents circumstances leading to the political, economic, and cultural cooperation in the post-communist CE is the above mentioned Visegrad Declaration of 1991. Poland, Czechoslovakia, and Hungary identified within it a set of corresponding political and economic conditions, as well as similar challenges arising from the need for systemic transformation. Among the main of them were: the restoration of sovereignty, democracy, and freedom; the liquidation of totalitarian system's remnants; the building up of parliamentary democracy and modern legal state; the building up of modern market economy; the full integration into the European political, economic, security, and legal systems ${ }^{25}$. Actions envisaged for the fulfilment of these objectives did not, however, specify any measures of their implementation. The wording of the 'practical steps' enumerated in the Declaration leaves much to be desired in terms of its substantive content. Provisions such as: development of cooperation and close contacts with European institutions or establishment of conditions for cooperation between enterprises and investments with foreign capital ${ }^{26}$ may be interpreted in many ways and do not assume any specific actions. This fact gives grounds to consider commitments made in the Declaration as a matter of intentions. Such reasoning makes sense when one acknowledges the normative dimension of this document. Particular

24 See for example A. Hasenclever, P. Meyer, V. Rittberger, "Integrating Theories of International Regimes", Review of International Studies, vol. 26, no. 1 (2000).

25 Declaration on Cooperation...

26

Ibid. 
paragraphs refer largely to the shared values, such as respect for cultural and spiritual heritage, fundamental human rights and freedoms, freedom of enterprise, the rule of law, democracy and tolerance. To a lesser extent do they refer to the community of interests which has emerged in CE after democratic changes and the collapse of bipolar system in international relations after 1989. Taking under consideration circumstances shaping political and economic situation in the post-communist Central Europe, one can distinguish two main premises providing reasons for the vague nature of adopted provisions and the introduction of informal model of the Visegrad cooperation.

\subsection{The state of unpredictability in Central Europe}

The first premise is unpredictability of the situation in which the CECs found themselves after the collapse of Communism. In all areas - ranging from political, through social and economic issues, and ending on security matters - major structural and mental changes have occurred. The basic principles of the political system, social norms, the main economic theories, and concepts of collective security were in the process of redefinition. The notion of 'transformation ${ }^{27}$ was generally embraced in order to describe the process of change - characterised by uneven pace. This state of uncertainty in the internal situation was strongly influenced by the lack of stability in the immediate surroundings. After the suspension of activity, and then dissolution of the Warsaw Pact $^{28}$ in 1991, there was a vacuum of political and military cooperation in CE. Subsequent cancelation of the Council for Mutual Economic Assistance (CMEA), established in 1949 in order to increase trade among the socialist states, left the CECs without any form of economic cooperation. In the face of unstable political situation in the USSR and on the territory of the former Socialist Federal Republic of Yugoslavia, members of the VG were interested in preserving stability in the region.

Taking into account neoliberal theory in IR, the creation of the VG resulted from the need to mitigate this regional state of unpredictability. The complex situation which has emerged in the region influenced the nature of the Visegrad cooperation. Its non-formal model of functioning and general meaning of objectives left room for shaping the scope and significance of its activities. Following the neoliberal presumption that states develop international (or regional) cooperation because they are interested in resolving common problems and seek the most effective form of collaboration ${ }^{29}$, the informal character of the VG should be perceived as a rational and justified decision

The process of transformation involved the introduction of political and economic reforms, such as the revision of legal system and constitutional structures, the establishment of a multiparty system, the repluralisation of associational life, the privatisation of state assets and the development of new private enterprises. See S.L. Wolchik, J.L. Curry, Central and East European Politics: From Communism to Democracy, Plymouth 2011, pp. 24-25.

28 A military alliance signed in 1955 between seven communist states of Central and Eastern Europe (Albania, Bulgaria, Czechoslovakia, East Germany, Hungary, Poland, and Romania) and the USSR as a response to the rearmament of the Federal Republic of Germany and its acceptance into NATO.

R. Keohane, After Hegemony..., p. 61. 
which resulted from the will to maintain a flexible form of cooperation. The main advantage behind such a solution was the ability to customise the activity of the grouping to changeable external conditions and maximise positive effects of cooperation. The informal nature of the VG was based on mutual consultations and meetings of the states' representatives: Cooperation of the signatories will be implemented through meetings and consultations carried out at different levels and in different forms ${ }^{30}$. From the perspective of neoliberal institutionalism, even such a non-binding commitment contributes to overcome barriers in multilateral relations, like distrust, uncertainty, or misinformation among states. By increasing opportunities and methods for information sharing, providing arenas for open discussion and negotiation between political elites and state actors, it should strengthen assurance and common expectations among the cooperating states ${ }^{31}$. This point of view provides grounds to perceive the creation of the VG not only as a tool of CECs for coordinating their transformation efforts, but as a vital channel of cooperation in numerous fields of action. Its non-formal organisation should be interpreted as a pragmatic response to the unstable situation in CE.

In accordance with neorealist theory in IR, states are dominant actors in international politics and their activity in international organisations and forums should be analysed through the prism of their national interest. The role and functioning of the Visegrad Group would be therefore determined by the existence of consensus among the CECs, following their own national interests. The restoration and strengthening of stability after the collapse of Communism in CE was undoubtedly a unifying objective among these states. It occupied the highest position in their domestic agendas ${ }^{32}$. Unpredictability of the political situation in their immediate surroundings was posing a common threat to the conduct of democratic and free market reforms: In autumn 1990 there were already serious problems emerging in Yugoslavia, and above all there was a general fear of unpredictable developments in the Soviet Union, where the Baltic States were on the verge of civil war ${ }^{33}$. The initial activity of the VG was justified to the extent to which it could reduce the level of unpredictability. It is noteworthy that the first stage of cooperation which covers the years 1991-1992, was dominated by the collaboration at the military level. Successive meetings of defence ministers and military staffs were devoted mainly to the issue concerning the withdrawal of Soviet troops from the territory of the Visegrad states. Such a development of cooperation within the Group might be well explained by neorealist theory which assumes that states are concerned mainly with their security and survival. The later turn of events seems to confirm this theoretical presupposition. After the change in domestic political objectives, which became visible in the aftermath of Czechoslovakia's split in 1993 and resulted in

30 Declaration on Cooperation...

$31 \quad$ R. Keohane, “Neoliberal Institutionalism...”, p. 150.

32 M. Szczepaniak, Państwa wyszehradzkie, systemy polityczne, gospodarka, wspótpraca (The Visegrad countries: Political Systems, Economy, Cooperation), Poznań 1996, p. 92.

33 M. Kopecek, “Politics, Antipolitics, and Czechs in Central Europe: The Idea of 'Visegrád Cooperation' and Its Reflection in Czech Politics in the 1990s", Questionable Return, vol. 12, no. 1 (2002), p. 6. 
the impasse of political cooperation, the military consultations continued with regular frequency ${ }^{34}$. This situation justifies the assumption that the informal nature of the VG resulted from a limited consensus among the CECs, which were interested in the achievement of particular gains (concerning their security) and were not willing to develop cooperation over that.

\subsection{The symbolic function of the VG}

The second premise underpinning the decision to rely on the informal model of cooperation is correlated with the symbolic function the Visegrad Group was expected to fulfil. Numerous references to fundamental values of European thought or universal bumanistic values contained in the Visegrad Declaration give grounds to acknowledge the normative dimension of cooperation. The emphasis on common cultural heritage between the CECs and the West, in parallel to the adoption of Western political and economic models, manifested a desire of the 'Return to Europe' ${ }^{35}$. The accepted objectives might be perceived as a clear message to the international community, confirming a pro-Western political and economic changes taking place in the CECs. Such an interpretation makes sense when one acknowledges that the leading purpose of the Visegrad cooperation was situated outside the region, i.e. the establishment of mutually beneficial cooperation with developed countries and European institutions ${ }^{36}$. This provision gives grounds to analyse the symbolic dimension of cooperation and take under consideration the common concerns of CECs about the external image of the VG. It is reasonable to assume that they were concerned not only about the reception from the side of Western European states, but also about the reaction of their past collaborator, the USSR and later Russia.

\subsubsection{Neoliberal perspective}

From a neoliberal perspective, the adoption of normative foundations at the beginning of cooperation should be perceived as a manifestation of states' intentions. By acknowledging the importance of liberal-democratic principles, such as liberty, democracy, respect for human rights and fundamental freedoms, the rule of law, etc., they were expressing their willingness to conduct democratic and free market economy reforms, as well as provide conditions for the emergence of civil society. Delimitation of common norms and values in pursuing state policy was expected to reduce the level of distrust and uncertainty in regional relations and thereby facilitate the cooperation within the VG. Such an interpretation derives from a general presupposition of neoliberal insti-

34 VG defense ministers held their meetings in Krakow in September 1993, Warsaw in January 1994, Budapest in May 1995, and Gdynia/Hel Peninsula in September 1996.

35 The notion refers to the political discourse in the new, emerging democracies in Central Europe after the fall of Communism. It expressed the willingness of CECs to rejoin Europe not only culturally, but also politically and economically. 
tutionalism that international or regional groupings may help states to achieve their common goals through the exchange of information and the provision of arenas for resolving disputes ${ }^{37}$. From this perspective, the adoption of normative principles in the Visegrad Declaration should be perceived as a way of enhancing both mutual and bilateral relations in the region. While one can demonstrate their positive effect on building trust in multilateral cooperation, it is difficult to prove their role in mitigating bilateral tensions.

At the beginning of the 1990s the VG has embraced the function of sharing information and providing arenas for consultations. It was engaged in working out common positions of CECs in the matters of regional concern, such as the withdrawal of Soviet troops, the association agreements with the European Communities (EC) or collaboration with the North Atlantic Treaty Organization (NATO). Successive meetings held at the highest governmental level and the preparation of declarations on the Group's further activities (Krakow Declaration of 1991, Prague Declaration of 1992) confirm that the level of trust in mutual relations was increasing. Simultaneously, the VG was unable to provide any mechanisms of resolving bilateral problems. There was no political will to touch upon the issue of intra-regional disputes, e.g. over the status and rights of the Hungarian minority in Slovakia, numbered around 700 thousand people ${ }^{38}$. This example gains in importance when one acknowledges that the protection of minority rights was included on the list of common values represented by the Visegrad states. Since no specific actions have been envisaged to safeguard these rights, one may perceive it as a preservation of status quo. The role of normative principles in building trust in bilateral relations has to be therefore recognised as limited.

Following another assumption of neoliberal institutionalism saying that states develop multilateral cooperation in a way that enables them to reach mutually beneficial outcomes $^{39}$, one should interpret the symbolic meaning of the Visegrad Declaration as an expected, intentional result. The adoption of general objectives, based on commonly identified values, gave the opportunity to create a positive image of the CECs' cooperation outside the region. An attempt to determine specific and measurable objectives, aiming for the resolution to the on-going problems in sub-regional relations, was more likely to cause the suspension of cooperation at an early stage of the VG's activity. One should be aware that at the beginning of the 1990s there were many unresolved issues in bilateral relations among the CECs. The majority of them concerned the Hungarian-Czechoslovak relations, and more specifically tensions between Hungarians and Slovaks. The above mentioned problem of the Hungarian minority in Slovakia constitutes only one example. The international dispute over the termination of GabčíkovoNagymaros Dams, situated on the border river of Danube, was an equally controversial issue. There were visible differences also in specific priorities of the foreign policy of particular CECs. Irrespectively of the fact that all of them regarded integration with

37 E.A. Heinze, B.J. Jolliff, “Idealism...”, p. 322.

38 M. Kopecek, 'Politics, Antipolitics..., p. 5.

39 R. Keohane, After Hegemony..., p. 97. 
European structures as the main objective, their perspectives in regional relations at the beginning of the 1990s were different. Hungary was re-establishing cooperation links with its Adriatic neighbours (Italy, Austria, and Yugoslavia) and already in 1989 became the founding member of the Quadragonale ${ }^{40}$. Poland was more interested in the relations with its new Eastern neighbours which emerged from the Soviet Union (Belarus, Ukraine) and with the Baltic States.

These obstacles and differences should not be omitted when explaining the model of cooperation within the VG from a neoliberal perspective. Their existence would be regarded as one more justification for a decision made by the CECs to base regional cooperation on normative foundations. It was a way of distancing themselves from the regional down-to-earth problems, but at the same time a point of departure for further cooperation. The adoption of common values should be therefore perceived as a stabilising factor and manifestation of conciliatory intentions.

\subsubsection{Neorealist perspective}

From a neorealist perspective, the symbolic meaning of the Visegrad Declaration should not be regarded as the result of CECs' intentions. Neorealist assumptions require the acknowledgement of particular interests and the role of external conditions in shaping the model of states' cooperation. When analysing the reasons determining the informal character of the VG and its normative foundations one should take under consideration a potential competition among its members. It should be also considered how much the VG members were able to gain $v i s-\dot{a}$-vis other regional states, which were not allowed to join the Group, such as Romania at the beginning of the $1990 \mathrm{~s}^{41}$. The absence of concrete and unambiguous provisions in the Visegrad Declaration, replaced by symbolic and non-binding commitments, ought to be interpreted as a result of the limited scope of mutual gains, which were outnumbered by particular gains. The symbolic function of the VG at an early stage of its activity would be therefore accounted for internal (intra-regional) and external limitations, what stays in accordance with the neorealist presupposition that international or regional cooperation has a limited capability to execute states' policies.

Internal limitations resulted not only from unresolved issues in bilateral relations but also from discrepancies in the economic development among the CECs. The state of economy in Czechoslovakia before the introduction of free-market reforms was much better in comparison with Poland and Hungary. The two latter were addition-

40 The Quadragonale was created in Budapest on 11 November 1989 by Italy, Austria, Hungary, and the Socialist Federal Republic of Yugoslavia as a forum of regional cooperation in Central, Eastern and South Eastern Europe. In 1990 Czechoslovakia was admitted to join the group, since then the Pentagonale. After the admission of Poland one year later, in 1991, it became the Hexagonale. Since 1992 and further enlargement to Macedonia, Bosnia and Herzegovina, Croatia, and Slovenia the organisation is called the Central European Initiative (CEI).

${ }^{41}$ R. Chmel, "My Visegrad Question” in A. Jagodziński (ed.), The Visegrad Group - A Central European Constellation, Bratislava 2006, p. 35. 
ally burdened with an obligation to pay back their large external debts. It suffices here to notice that in the case of Poland this debt in 1990 amounted to $\$ 35.5$ billion and was the largest one of the former satellites'. In Hungary it was $\$ 13.7$ billion (the largest debt per head of population) and in Czechoslovakia 'only' $\$ 4$ billion $^{42}$. Poland's debt accounted for $82 \%$ in relation to GDP ${ }^{43}$, whereas in Czechoslovakia it was about $7 \%{ }^{44}$. These data illustrate that the point of departure in adjusting to and becoming competitive with Western European economies differed, depending on a particular CEC. Taking this into account, one should acknowledge that the position of Czechoslovakia as a candidate for the integration with the EC was objectively stronger than Polish and Hungarian, at least in economic terms. However, the overall economic potential of Poland, constituting the biggest domestic market in the region, contributed to its higher relevance as a trading partner for the EC member states. Poland seemed to be more important than other CECs also from a geopolitical point of view, since it could have been regarded as a corridor between Western Europe and the postsoviet Eastern Europe with Russia, or as a defender of the former's Eastern borders (depending on the situation). Different conditions and varying economic and strategic potential represented by particular CECs provided them with a perspective to advance their integration process with European institutions irrespectively of the others. The symbolic and non-binding character of cooperation within the VG may be regarded as a consequence of this individual approach in striving for the quickest entry into European structures, which manifested itself after the change in governments in the CECs in the years 1992-1993. It was symbolised by the socalled 'policy of exclusivity' adopted by Vaclav Klaus in the Czech Republic (CR) after the dissolution of Czechoslovakia in 1993. In his conception of foreign policy, the adoption of closer political and economic links among the VG states could have impeded the pace of transformation in a leading state (the CR) by involving it in the problems and backwardness of the others ${ }^{45}$. Although this language of national interest was not used by Vaclav Havel and the other founding fathers of the VG, one cannot exclude a hypothesis that the informal structure of cooperation was more favourable for them because of similar reasons. A nonformal setting made the CECs less dependent upon each other on their way to the EC/ EU and NATO.

The external factors which were likely to influence the decision on the informal Visegrad cooperation, based on normative foundations, can be recognised both to the West and to the East of CE. As it has been noticed when discussing the provisions of the Visegrad Declaration, the main objective of cooperation was referred to the so-called 'Return to Europe'. The development of closer (and formalised) re-

42 P. Calvocoressi, World Politics Since 1945, Harlow 2009, p. 248.

43 Z. Szpringer, "Publiczne zadłużenie zagraniczne Polski z perspektywy historycznej" (Public Foreign Debt in Poland Seen from the Historical Perspective), Analizy BAS, vol. 69, no. 2 (2012), p. 7.

44 Struktura a vývoj státního dlubu (The Structure and Evolution of Domestic Debt), Ministry of Finance of the Czech Republic, [online] www.mfcr.cz/cs/verejny-sektor/hospodareni/rizeni-statniho-dluhu/ dluhova-statistika/struktura-a-vyvoj-statniho-dluhu, 10 II 2014. 
lations with the European political, economic, and military groupings was the priority at the regional and national level. When one takes into account the neorealist assumption that states cooperate in order to pursue their particular interests, the early VG should be regarded as an instrument adapted to the ultimate end - the rightful membership in European structures. Its expected role as an agent in achieving EU and NATO membership, manifested clearly in the Visegrad Declaration by its signatories' desire to achieve a complete integration into the political, economic, security, and legal systems in Europe, must have influenced the grouping's way of organisation. Such a reasoning gives grounds to claim that the early character and scope of cooperation in $\mathrm{CE}$ was subordinated to the reaction and expectations of European and, more generally, Western structures. Two most relevant of them, the EC/EU and NATO, were interested in the development of regional cooperation in CE because it was a premise of stabilisation in the larger area of Central and Eastern Europe. At the beginning of the 1990s this region was lacking in stability and the consequences of the Soviet Union's declining power were unpredictable. The possibility of an outbreak of war in the aftermath of the USSR's dissolution was posing a threat to the security of Western European states, which justifies their then support to the cooperation emerging in $\mathrm{CE}$ (provided by the EC and NATO). In this context one can invoke the words of a Czech politician, Vaclav Klaus, who stated that: Visegrád [Group] is not relevant at all. It was a process that was artificially provoked by Western countries ${ }^{46}$. Such an opinion refers largely to the neorealist way of thinking, which subordinates state's intentions to the external (or systemic) conditioning. The establishment of the VG should be consequently recognised as a response to Western expectations of democratic transformation and peaceful cooperation in CE. Its informal and symbolic character would in turn account for its limited capabilities and subordination to the ultimate objective - the membership in the EC/ EU and NATO. The development of an independent structure of cooperation in CE, with a clear-cut functional nature, could have impeded the achievement of this objective, since regarded from the outside as an alternative organisation ${ }^{47}$.

Another external limitation was constituted by the implications of the on-going CECs' participation in the Eastern Bloc institutional framework. It should be reminded here that at the beginning of 1991 the CECs were still the members of two groupings established in the framework of the Eastern Bloc and dominated by the Soviet Union.

46 V. Leska et al., "Ceská republika a region strední Evropy" (Czech Republic and the Region of Central Europe) in V. Kotyk, Ceská zahranicni politika. Úvahy o prioritách (Czech Foreign Policy. Considerations about Priorities), Prague 1997, p. 114.

47 Because of its original objective to support and promote the CECs' integration with European/ Western structures, Martin Dangerfield suggests perceiving the early VG as a complement/pre-accession instrument among other types of subregional groupings (pioneer, substitute, and involuntary alternative/substitute). As he points out, the initial reluctance of participants to engage in subregional integration is a characteristic feature of this type. Their aspirations to join larger and more developed regional structures in the future hinder the deepening of subregional cooperation, as it may bring negative effects on their accession plans. M. Dangerfield, "The Visegrád Group in the Expanded European Union: From Pre-accession to Post-accession Cooperation”, East European Politics and Society, vol. 22, no. 3 (2008), p. 633, [online] DOI: 10.1177/0888325408315840. 
This refers to the CMEA and the Warsaw Pact. The pursuit of CECs to leave the economic and military alliance with its Eastern neighbours and reorient their foreign policy priorities towards integration with the West included a risk of retaliation from the USSR. The latter was interested in maintaining its sphere of influence in Central Europe, what may be proved by the fact that at the beginning of the 1990s it insisted on the revival of economic cooperation in the frame of CMEA. These developments forced the CECs to harmonise their policies towards the USSR and exert joint pressure on it to curtail the activity of CMEA and the Warsaw Pact. From this perspective, the establishment of the VG may be regarded as an embodiment of this need ${ }^{48}$. The meaning of the objectives formulated by CECs could not be, however, too confrontational in relation to the USSR, their outgoing major economic and strategic partner. In practice, all signatories of the Visegrad Declaration were interested in maintaining good relations with the Soviet Union, nevertheless, free from any form of subordination ${ }^{49}$. In the text of Declaration there are no direct references to the expected dissolution of CMEA or the Warsaw Pact. The only provisions which may be interpreted as a manifestation of the will to abandon these groupings are the following: the restoration of country's sovereignty, democracy and freedom and the liquidation of totalitarian system's remnants ${ }^{50}$. Their indirect and non-confrontational meaning should be accounted for a security dilemma emerging in CE after 1989/1990 and resulting from a desire of CECs to leave the then-present military alliance, even though lacking security guarantees from the side of Western states. The presence of the Soviet army in CE was additionally limiting the possibility of adopting firm provisions.

Following a neorealist perspective, one should notice one more reason determining the symbolic meaning of the Visegrad Declaration. It refers to the assumption that the CECs, driven by their particular interests, decided to establish the VG in order to gain importance $v i s-\dot{a}-v i s$ other post-Communist states. The emphasis on a common cultural and spiritual heritage of Central Europe as well as reference made to the historical background of regional cooperation reveal some characteristics of self-interested behaviour ${ }^{51}$. Aside from presenting the distinctiveness of Central Europe

48 The initial years of the Visegrad cooperation were devoted to foreign policy issues. The process of eliminating divisions among the CECs regarding alternate visions of security strategies for Central Europe and unifying their stance towards the Soviet Union and the West started already in 1990. In April that year the first post-communist leaderships of CECs met in Bratislava to discuss prospects of future cooperation. The meeting, initiated by Vaclav Havel, provided grounds for the signing of the Visegrad Declaration in 1991 and adoption of a common agenda which included the quickest possible dissolution of the Warsaw pact. The achievement of this goal in July 1991 and the following disbandment of CMEA manifests the effectiveness of cooperation in its early days. Citation from: J. Dienstbier, "Visegrad: The First Phase" in A. Jagodziński, The Visegrad Group..., p. 42.

49 J.K. Bielecki, "Through Visegrad to the West” in A. Jagodziński, The Visegrad Group..., p. 31.

50 Declaration on Cooperation...

51 The content of the 1991 Visegrad Declaration does not specify any historical form of regional cooperation. However, the place where it was signed is related to to the meeting of three kings (Hungarian, Polish, and Czech) in 1335, held to discuss cooperation. Visegrad was deliberately chosen as a symbol of cooperation among the Central European states. 
from Eastern Europe - identified then as a sphere of Soviet influence ${ }^{52}$, it provided the VG states with an argument to maintain an exclusive character of their grouping. The argument has been used as a justification of the negative response to the Romanian request to join the Group in 1991. It has to be mentioned that democratic standards and economic situation in Romania were at that time considerably below the level represented by the CECs. Its acceptance to the VG was likely to impede the process of integration with European structures by creating more visible discrepancies inside the Group. By rejecting Romania, the VG states gave precedence to neorealism in explaining their behaviour. This decision provided solid grounds to claim that the symbolic dimension of cooperation, as well as the establishment of the Group in general, was not expected to be an end in itself, but rather a temporary instrument of executing particular interests of CECs.

\section{CONCLUSION}

The above analysis of premises explaining the reluctance to institutionalise the VG has demonstrated that two seemingly contradictory theories in IR - neorealism and neoliberal institutionalism can both provide a reasonable explanation of states' behaviour in mutual relations. However, the main objective adopted in this paper was to reveal which one enables us to formulate more credible justification for a decision made by the CECs to cooperate without formal structures. This decision was successively considered as a potential result of the common intention to facilitate cooperation and as a preservation of particular national interests. The first option was derived from the neoliberal presupposition that states believe that international cooperation helps them make mutually beneficial agreements ${ }^{53}$. The second one was deducted from the neorealist conviction that even when cooperating for a mutual aim, states remain concern how much they can gain vis-ád-vis each other or in relation to the third states ${ }^{54}$.

The results of comparative analysis have found that the second explanation is more credible. It justifies the adoption of informal and nonbinding model of the Visegrad cooperation by the fact that it was more practical than institutional ties. In the context of unpredictable political developments in the immediate surroundings of CECs at the beginning of the 1990s, such a solution provided the opportunity to harmonise their efforts to achieve common goals: the withdrawal of Soviet troops and the establishment of relations with European structures (the EC) and NATO. Simultaneously, it left a prospect of pursuing more self-oriented foreign policy after the achievement of these short-term goals. An attempt made to conduct alternative reasoning and present the informal setting of the VG as the first step towards more comprehensive cooperation in the future has proved to be difficult to sustain. It did not provide a satisfactory

\footnotetext{
52 T.G. Ash, "The Puzzle of Central Europe" in A. Jagodziński (ed.), The Visegrad Group..., p. 114.

53 R. Keohane, After Hegemony..., p. 88.

54 E.A. Heinze, B.J. Jolliff, „Idealism...”, p. 324.
} 
explanation for the reluctance of CECs to negotiate within the Group downtoearth regional problems and resolve bilateral disputes - a prerequisite for trustful future relations. Their selective approach to fulfilling joint declarations has revealed that the VG was regarded as an instrument of achieving above goals, not as a value in itself. Neorealist theory in IR explains effectively its instrumental role in executing the interests of CECs. However, it does not enjoy a monopoly on explaining the VG's informal nature. It is recommended to contrast the former with a neoliberal perspective in order to gain a thorough understanding of this phenomenon.

\section{REFERENCES}

\section{Books:}

\section{Reference literature:}

- monographs:

Calvocoressi P., World Politics Since 1945, Harlow 2009.

Jørgensen K.E., International Relations Theory. A New Introduction, London 2010.

Keohane R., After Hegemony: Cooperation and Discord in the World Political Economy, Princeton 1984.

Szczepaniak M., Państwa wyszehradzkie, systemy polityczne, gospodarka, wspótpraca (The Visegrad countries: Political Systems, Economy, Cooperation), Poznań 1996.

Waltz K., Theory of International Politics, New York 1979.

- collective works:

Keohane R., Nye J., Power and Interdependence, New York 2001.

Morgenthau H.J., Thompson K.W., Politics Among Nations: The Struggle for Power and Peace, New York 1985.

Wolchik S.L., Curry J.L., Central and East European Politics: From Communism to Democracy, Plymouth 2011.

- chapters in collective works:

Ash T.G., "The Puzzle of Central Europe" in A. Jagodziński (ed.), The Visegrad Group A Central European Constellation, Bratislava 2006.

Ben-Itzhak S., "Realism and Neorealism" in J.T. Ishiyama, M. Breuning (eds.), $21^{\text {st }}$ Century Political Science: A Reference Handbook, 2011.

Bielecki J.K., "Through Visegrad to the West" in A. Jagodziński (ed.), The Visegrad Group A Central European Constellation, Bratislava 2006.

Chmel R., "My Visegrad Question" in A. Jagodziński (ed.), The Visegrad Group - A Central European Constellation, Bratislava 2006.

Dienstbier J., "Visegrad: The First Phase" in A. Jagodziński (ed.), The Visegrad Group A Central European Constellation, Bratislava 2006.

Heinze E.A., Jolliff B.J., "Idealism and Liberalism" in J.T. Ishiyama, M. Breuning (eds.), $21^{s t}$ Century Political Science: A Reference Handbook, 2011. 
Keohane R., "Neoliberal Institutionalism: A Perspective on World Politics" in Keohane R. (ed.), International institutions and state power: Essays in international relations theory, Boulder 1989.

Keohane R., Martin L., "Institutional Theory as a Research Program" in C. Elman, M.F. Elman (eds.), Progress in International Relations Theory: Appraising the Field, Cambridge, MA 2003.

Leska V., Dancák B., Mares M., Morvay P., “Ceská republika a region strední Evropy” (Czech Republic and the Region of Central Europe) in V. Kotyk (ed.), Ceská zahranicni politika. Úvahy o prioritách (Czech Foreign Policy. Considerations about Priorities), Prague 1997.

Waltz K., "Realist thought and neorealist theory" in R.L. Rothstein, W.T.R. Fox (eds.), The Evolution of Theory in International Relations, Columbia 1992.

- articles in scientific journals:

Andreatta F., Koenig-Archibugi M., "Which Synthesis? Strategies of Theoretical Integration and the Neorealist-Neoliberal Debate", International Political Science Review, vol. 31, no. 2 (2010), [online] DOI: http://dx.doi.org/10.1177/0192512110364258.

Axelrod R., Keohane R., "Achieving Cooperation under Anarchy: Strategies and Institutions", World Politics, vol. 38, no. 1 (1985).

Dangerfield M., “The Visegrád Group in the Expanded European Union: From Preaccession to Postaccession Cooperation", East European Politics and Society, vol. 22, no. 3 (2008), [online] DOI: 10.1177/0888325408315840.

Hasenclever A., Meyer P., Rittberger V., "Integrating Theories of International Regimes”, Review of International Studies, vol. 26, no. 1 (2000).

Jervis R., "Realism, Neoliberalism, and Cooperation. Understanding the Debate", International Security, vol. 24, no. 1 (1999).

Kopecek M. "Politics, Antipolitics, and Czechs in Central Europe: The Idea of 'Visegrád Cooperation' and Its Reflection in Czech Politics in the 1990s", Questionable Return, vol. 12, no. 1 (2002).

Mearsheimer J.J., “The False Promise of International Institutions”, International Security, vol. 19 , no. 3 (1994/1995).

Szpringer Z., "Publiczne zadłużenie zagraniczne Polski z perspektywy historycznej" (Public Foreign Debt in Poland Seen from the Historical Perspective), Analizy BAS, vol. 69, no. 2 (2012).

- articles:

Kundera M., "The Tragedy of Central Europe”, The New York Review of Books, 26 IV 1984.

\section{Electronic publications:}

\section{Reference literature:}

Declaration on Cooperation between the Czech and Slovak Federal Republic, the Republic of Poland and the Republic of Hungary in Striving for European Integration, adopted in Visegrád on 15 February 1991, the Visegrad Group website, [online] http://www.visegradgroup.eu/ documents/visegrad-declarations/visegrad-declaration-110412. 
Struktura a vývoj státniho dlubu (The Structure and Evolution of Domestic Debt), Ministry of Finance of the Czech Republic, [online] http://www.mfcr.cz/cs/verejny-sektor/ hospodareni/rizeni-statniho-dluhu/dluhova-statistika/struktura-a-vyvoj-statniho-dluhu.

\section{Websites:}

Official website of the Visegrad Group - http://www.visegradgroup.eu.

Marcin CHRUŚCIEL, graduate of the Jagiellonian University European Studies, and a student of the $2^{\text {nd }}$ year of M.A. programme in International Relations: Europe in the Visegrad Perspective at the Jagiellonian University, Masaryk University (Brno), University of Pécs, and Matej Bel University (Banská Bystrica). His main research interests are the course of regional cooperation in Central Europe, and especially the activities of the Visegrad Group, on which subject he wrote and defended his M.A. thesis entitled The Activity of the Visegrad Group in the Years 1991-2004 as a Process of Establishing Regional Co-operation in Central Europe. He is interested in European cinema and photography. 